\title{
Some Challenges for Forest Fire Risk Predictions in the 21st Century
}

\author{
Víctor Resco de Dios ${ }^{1,2,3, *(D)}$ and Rachael H. Nolan 4,5 (D) \\ 1 School of Life Science and Engineering, Southwest University of Science and Technology, \\ Mianyang 621010, China \\ 2 Department of Crop and Forest Sciences, Universitat de Lleida, 25198 Lleida, Spain \\ 3 Joint Research Unit CTFC-AGROTECNIO, Universitat de Lleida, 25198 Lleida, Spain \\ 4 Hawkesbury Institute for the Environment, Western Sydney University, Locked Bag 1797, \\ Penrith, NSW 2751, Australia; Rachael.Nolan@westernsydney.edu.au \\ 5 Bushfire Risk Management Research Hub, Wollongong, NSW 2522, Australia \\ * Correspondence: v.rescodedios@swust.edu.cn
}

Citation: Resco de Dios, V.; Nolan, R.H. Some Challenges for Forest Fire Risk Predictions in the 21st Century. Forests 2021, 12, 469. https:// doi.org/10.3390/f12040469

Received: 7 April 2021

Accepted: 11 April 2021

Published: 12 April 2021

Publisher's Note: MDPI stays neutral with regard to jurisdictional claims in published maps and institutional affiliations.
Global wildfire activity has experienced a dramatic surge since 2017. From Chile [1] to Indonesia [2], unprecedented fire behavior has occurred in many areas worldwide including, but not limited to, Portugal [3], Siberia [4], Australia [5,6], the Amazon and Orinoco basins [7], and the Western US [8]. This surge in global wildfire activity has led to a dramatic raise in human fatalities, and in socio-economic and ecological losses.

Wildfires have been ravaging through both fire-prone and non-fire-prone ecosystems. Although wildfires are regarded as a natural phenomenon in fire-prone ecosystems, and are necessary for the successful establishment and regeneration of many species, their positive effects are limited to instances in which the current fire regime resembles that under which the affected species evolved [9]. As the components of the fire regime change because of global change (including the frequency, intensity, and timing of forest fires), many species will experience a novel disturbance regime and, consequently, we can expect a reorganization in many ecosystems worldwide, potentially shifting towards an increase in ruderal species (ruderalization) [10].

Wildfires have also become increasingly common in many non-fire-prone ecosystems [11]. We have observed dramatic wildfires in the rainforests of the Amazon associated with deforestation, land use change, and other processes [12]. Additionally, increasing numbers of holdover fires beyond the Arctic circle, which resurface after burning underground during the winter, have been linked to a proliferation of spring and summer surface wildfires in the Arctic [4]. The effects of catastrophic wildfire on non-fire-prone ecosystems will be even more dramatic than in fire-prone ecosystems.

The currently ongoing, global change-induced, intensification of the fire regime has escalated from being primarily an ecological problem to also becoming a civil protection issue. For example, in Southern Europe, the number of wildfire fatalities over the last 13 years (473 fatalities) $[13,14]$ has exceeded the number of fatalities in terrorist attacks in the entire European Union (448 victims) [15] (Figure 1). Wildfires also potentially pose a security threat by directly threatening defense infrastructure and diverting defense personnel to provide humanitarian assistance and disaster relief, as occurred during the 2019/2020 fire season in Australia [16]. 


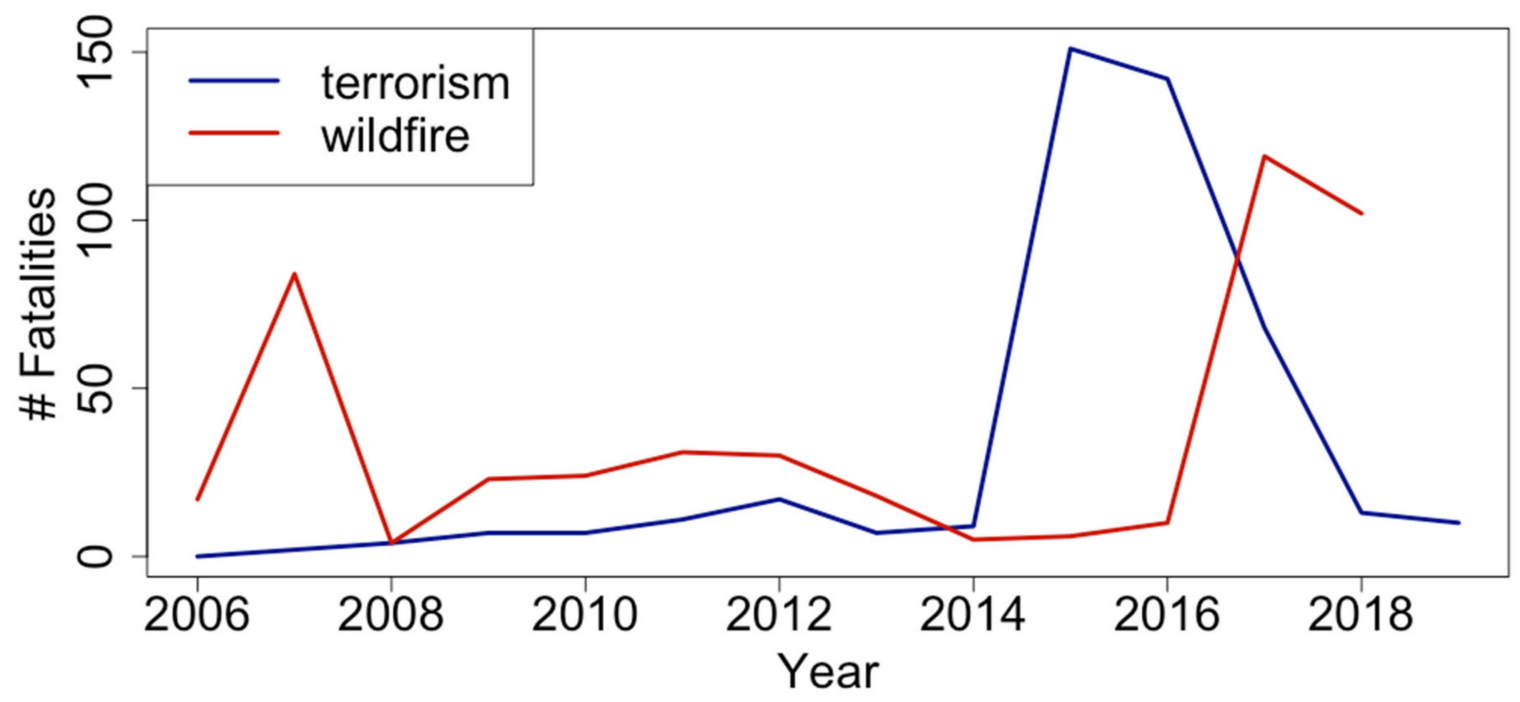

Figure 1. The number of fatalities resulting from wildfires is now larger than the number of terrorism victims in the European Union. We compiled data on people killed by terrorism in the EU since Europol TE-SAT reports [15] started in 2006 with data on wildfire fatalities for Southern Europe (Portugal, Spain, Greece, and Sardinia) $[13,14]$.

Wildfires are also becoming an increasing public health issue. Smoke from wildfires is currently estimated to be the direct cause of death of 339,000 people annually [17], and there is a well-documented increase in hospital admissions due to smoke-enhanced cardiovascular and respiratory conditions, amongst others [18]. In interaction with the current pandemic, wildfire smoke could increase hospital admissions by $10 \%$ in areas affected by large wildfire [19]. Wildfires could also act as vectors for transporting airborne pathogens [20].

Extreme wildfires are also extending their impacts to an increasing range of sectors, including agriculture, infrastructure, transport, and tourism, to name a few, resulting in declines in consumer activity and large economic impacts [21].

Wildfires also alter the climatic system in a myriad of ways. Direct effects include enhanced carbon emissions, currently estimated at $\sim 10 \%$ of fossil fuel emissions [22]. However, other contributions are more difficult to quantify. Wildfires alter albedo, with important consequences for the energy balance and fostering warming in tropical, but cooling in boreal ecosystems [23]. Wildfires also affect the water balance [24], and the capacity for future $C$ sequestration in burned ecosystems may be reduced, relative to that prior to fire, when wildfires induce large-scale land degradation [9].

All in all, it appears that we are simply witnessing the "preview" of the havoc that climate change will bring for future fire regimes. In fact, a commonality across all the changes in the fire regime previously mentioned was a very marked increase in vapor pressure deficit, a very marked driver of fire activity [25,26], resulting from living in a $1{ }^{\circ} \mathrm{C}$ warmer world. As climate projections for the end of the century converge into a likely $3{ }^{\circ} \mathrm{C}$ warming scenario [27], we can expect, at least in the short term, a further intensification of the fire regime.

Increases in fire danger induced by climate change call for a re-evaluation of current approaches for assessing the likelihood of a catastrophic fire. Seasonal changes in wildfire likelihood result from changes in fuel moisture and in fire weather that, when an ignition source is provided, can lead to catastrophic wildfire if fuel build up is large enough [28]. The challenge lies in developing a quantitative and mechanistic understanding of fire danger that is deep enough to allow accurate forecasting, yet simple enough that can be used for operational purposes.

Traditional approaches for forecasting seasonal changes in fire weather relied on developing fire weather and danger indices that, often, seek to estimate fuel moisture and potential fire spread depending on past meteorological conditions. These indices have 
shown mixed success in predicting fire danger [29,30], and they have not been exempt from criticism [31]. Developing an early warning system for catastrophic fire, which predicts when and where critical wildfires will occur, as well as educating the populace on how to interpret these predictions, has become an increasing necessity [3].

Understanding changes in fire danger requires integration across multiple spatial and temporal scales: from leaves to regions, and from days to decades. This was the motivation to put forward this Special Issue on Forest Fire Risk Prediction: to provide the tools for improving fire danger forecasts in the 21st century. The Special Issue comprises 13 articles, touching upon different aspects of fire danger along a continuum of scales.

Broadly speaking, the articles contained in this Special Issue can be grouped into four topics. The first topic is the use of fire danger metrics and other approaches to understand variation in wildfire activity. The opening article by Fernandes [32] examines the thresholds in a widespread indicator of fire danger, the Fire Weather Index (FWI), associated with wildfires of different sizes across Portugal. Varela et al. [33] use the FWI to identify future vulnerability of archaeological and touristic sites in Greece. The study of Ma et al. [34] presents a broad assessment on the drivers of wildfire activity in China using random forest algorithms, and the study by Milanović et al. [35] additionally compares random forest with logistic regressions to estimate fire probability in Serbia. Zong et al. [36] uses a historical analysis of the drivers of forest fire in Central Asia to project changes under climate change in the 21st century.

The second topic covered by this Special Issue is devoted to understanding changes in the flammability of live fuel. Nolan et al. [37] review the mechanisms driving live fuel moisture content and propose a novel model that moves the field forward. Balaguer-Romano et al. [38] explore the hypothesis that needle senescence could affect wildfire behavior in Mediterranean pine forests. How to provide regional estimates of live fuel moisture content is explored by Luo et al. [39], who provide a case study for SW China. Della Rocca, et al. [40] address interactions between pathogen infections and flammability. Also along these lines, Collins et al. [41] address the effects of repeated fires on burn severity.

The third topic covered in this Special Issue is modeling dead fuel moisture content. Zhang and Sun [42] compare two methods for estimating diurnal changes in fine litter moisture. Log [43] further assesses moisture diffusion coefficients in Calluna vulgaris to better inform prescribed fire practices.

Finally, the study of Ma et al. [44] compares the emission factors of Chinese tree species ranging from Boreal to subtropical environments, and they present intriguing evidence indicating that wildfires could acidify forest ecosystems because of emissions. This varied collection of articles indicates that progress in fire danger predictions comes from a multidisciplinary and varied approach.

The cradle of Western civilization lies in Ancient Greece. They laid the foundations of science and democracy. As climate change intensifies worldwide, wildfires are even threatening the archaeological remains from Ancient Greece [33]. In his work The Republic, the Greek philosopher Plato wrote the Allegory of the Cave, where men living in the bottom of a cave perceived reality only through shadows and they were afraid of reaching out of the cave to see reality as it is. The only escapee from the cave who saw the actual world was the one who embraced knowledge. If we have any chance to prevent the worsening of the wildfire problem, we need now, more than ever, to resort back to logic and reason. This Special Issue is a testament to the fact that we have the knowledge and technical capability to anticipate the effects of global warming on wildfires. The challenge lies in convincing policy makers, managers, stakeholders, and all the other actors involved to follow through and take evidence-based decisions. The challenge lies in getting out of Plato's cave.

Author Contributions: Writing: V.R.d.D. and R.H.N. All authors have read and agreed to the published version of the manuscript. 
Funding: V.R.d.D. acknowledges funding from the National Natural Science Foundation in China (U20A20179, 31850410483), the talent proposals in Sichuan Province (2020JDRC0065), from Southwest University of Science and Technology (18ZX7131), and the MICINN (RTI2018-094691-B-C31). R.H.N. was supported with funding from the New South Wales Department of Planning, Industry and Environment, via the NSW Bushfire Risk Management Research Hub.

Acknowledgments: We appreciate the comments that Dick Williams, Rob Whelan, and Matthias Boer provided on an earlier version of this article.

Conflicts of Interest: The authors declare no conflict of interest.

\section{References}

1. Gómez-González, S.; Ojeda, F.; Fernandes, P.M. Portugal and Chile: Longing for sustainable forestry while rising from the ashes. Environ. Sci. Policy 2018, 81, 104-107. [CrossRef]

2. Rochmyaningsih, D. Scientists in indonesia fear political interference. Science 2020, 367, 722. [CrossRef] [PubMed]

3. Boer, M.M.; Nolan, R.H.; Resco De Dios, V.; Clarke, H.; Price, O.F.; Bradstock, R.A. Changing weather extremes call for early warning of potential for catastrophic fire. Earth's Future 2017, 5, 1196-1202. [CrossRef]

4. McCarty, J.L.; Smith, T.E.L.; Turetsky, M.R. Arctic fires re-emerging. Nat. Geosci. 2020, 13, 658-660. [CrossRef]

5. Nolan, R.H.; Boer, M.M.; Collins, L.; Resco de Dios, V.; Clarke, H.; Jenkins, M.; Kenny, B.; Bradstock, R.A. Causes and consequences of eastern Australia's 2019-20 season of mega-fires. Glob. Chang. Biol. 2020, 26, 1039-1041. [CrossRef] [PubMed]

6. Boer, M.M.; Resco de Dios, V.; Bradstock, R.A. Unprecedented burn area of australian mega forest fires. Nat. Clim Chang. 2020, 10, 171-172. [CrossRef]

7. Barlow, J.; Berenguer, E.; Carmenta, R.; França, F. Clarifying amazonia's burning crisis. Glob. Chang. Biol. 2020, 26, 319-321. [CrossRef]

8. Pickrell, J.; Pennisi, E. Record U.S. and australian fires raise fears for many species. Science 2020, 370, 18-19. [CrossRef]

9. Resco de Dios, V. Plant-Fire Interactions. In Applying Ecophysiology to Wildfire Management; Springer: Cham, Switzerland, 2020; Volume 36.

10. Karavani, A.; Boer, M.M.; Baudena, M.; Colinas, C.; Díaz-Sierra, R.; Pemán, J.; de Luís, M.; Enríquez-de-Salamanca, Á.; Resco de Dios, V. Fire-induced deforestation in drought-prone mediterranean forests: Drivers and unknowns from leaves to communities. Ecol. Monogr. 2018, 88, 141-169. [CrossRef]

11. Boer, M.M.; Resco De Dios, V.; Stefaniak, E.Z.; Bradstock, R.A. A hydroclimatic model for the distribution of fire on earth. Environ. Res. Commun. 2021, 3, 035001. [CrossRef]

12. Armenteras, D.; González, T.M.; Vargas Ríos, O.; Meza Elizalde, M.C.; Oliveras, I. Incendios en ecosistemas del norte de Suramérica: Avances en la ecología del fuego tropical en Colombia, Ecuador y Perú. Caldasia 2020, 42, 1-16. [CrossRef]

13. Molina-Terrén, D.M.; Xanthopoulos, G.; Diakakis, M.; Ribeiro, L.; Caballero, D.; Delogu, G.M.; Viegas, D.X.; Silva, C.A.; Cardil, A. Analysis of forest fire fatalities in southern europe: Spain, Portugal, Greece and Sardinia (Italy). Int. J. Wildland Fire 2019, $28,85$. [CrossRef]

14. Haynes, K.; Short, K.; Xanthopoulos, G.; Viegas, D.; Ribeiro, L.M.; Blanchi, R. Wildfires and Wui Fire Fatalities. In Encyclopedia of Wildfires and Wildland-Urban Interface (WUI) Fires; Manzello, S.L., Ed.; Springer: Cham, Switzerland, 2020; pp. 1-16.

15. Europol. Eu Terrorism Situation \& Trend Report (Te-Sat). Available online: http:/ / www.europol.europa.eu/tesat-report?page=0,1 (accessed on 15 September 2020).

16. McDonald, M. After the fires? Climate change and security in australia. Aust. J. Political Sci. 2021, 56, 1-18. [CrossRef]

17. Johnston, F.H.; Henderson, S.B.; Chen, Y.; Randerson, J.T.; Marlier, M.; Defries, R.S.; Kinney, P.; Bowman, D.M.; Brauer, M. Estimated global mortality attributable to smoke from landscape fires. Environ. Health Perspect. 2012, 120, 695-701. [CrossRef]

18. Borchers Arriagada, N.; Palmer, A.J.; Bowman, D.M.; Morgan, G.G.; Jalaludin, B.B.; Johnston, F.H. Unprecedented smoke-related health burden associated with the 2019-20 bushfires in eastern australia. Med. J. Aust. 2020, 213. [CrossRef] [PubMed]

19. Henderson, S.B. The covid-19 pandemic and wildfire smoke: Potentially concomitant disasters. Am. J. Public Health 2020, 110, 1140-1142. [CrossRef]

20. Kobziar, L.N.; Thompson, G.R. Wildfire smoke, a potential infectious agent. Science 2020, 370, 1408-1410. [PubMed]

21. Filkov, A.I.; Ngo, T.; Matthews, S.; Telfer, S.; Penman, T.D. Impact of australia's catastrophic 2019/20 bushfire season on communities and environment. Retrospective analysis and current trends. J. Saf. Sci. Resil. 2020, 1, 44-56. [CrossRef]

22. Le Quéré, C.; Andrew, R.M.; Friedlingstein, P.; Sitch, S.; Hauck, J.; Pongratz, J.; Pickers, P.A.; Korsbakken, J.I.; Peters, G.P.; Canadell, J.G.; et al. Global carbon budget 2018. Earth Syst. Sci. Data 2018, 10, 2141-2194. [CrossRef]

23. Chapin, F.S.; Randerson, J.T.; McGuire, A.D.; Foley, J.A.; Field, C.B. Changing feedbacks in the climate-biosphere system. Front Ecol. Environ. 2008, 6, 313-320. [CrossRef]

24. Nolan, R.H.; Lane, P.N.J.; Benyon, R.G.; Bradstock, R.A.; Mitchell, P.J. Changes in evapotranspiration following wildfire in resprouting eucalypt forests. Ecohydrology 2014, 7, 1363-1377. [CrossRef]

25. Resco de Dios, V.; Fellows, A.W.; Nolan, R.H.; Boer, M.M.; Bradstock, R.A.; Domingo, F.; Goulden, M.L. A semi-mechanistic model for predicting the moisture content of fine litter. Agric. For. Meteorol. 2015, 203, 64-73. 
26. Nolan, R.H.; Resco de Dios, V.; Boer, M.M.; Caccamo, G.; Goulden, M.L.; Bradstock, R.A. Predicting dead fine fuel moisture at regional scales using vapour pressure deficit from modis and gridded weather data. Remote. Sens. Environ. 2016, 174, 100-108. [CrossRef]

27. Hausfather, Z.; Peters, G.P. Emissions-The 'business as usual' story is misleading. Nature 2020, 577, 618-620. [CrossRef]

28. Bradstock, R.A. A biogeographic model of fire regimes in Australia: Current and future implications. Glob. Ecol. Biogeogr. 2010, 19, 145-158. [CrossRef]

29. Di Giuseppe, F.; Vitolo, C.; Krzeminski, B.; Barnard, C.; Maciel, P.; San-Miguel, J. Fire weather index: The skill provided by the european centre for medium-range weather forecasts ensemble prediction system. Nat. Hazards Earth Syst. Sci. 2020, 20, 2365-2378. [CrossRef]

30. Bedia, J.; Herrera, S.; Gutiérrez, J.M.; Benali, A.; Brands, S.; Mota, B.; Moreno, J.M. Global patterns in the sensitivity of burned area to fire-weather: Implications for climate change. Agric. For. Meteorol. 2015, 214-215, 369-379. [CrossRef]

31. Ruffault, J.; Martin-StPaul, N.; Pimont, F.; Dupuy, J.-L. How well do meteorological drought indices predict live fuel moisture content (lfmc)? An assessment for wildfire research and operations in mediterranean ecosystems. Agric. For. Meteorol. 2018, 262, 391-401. [CrossRef]

32. Fernandes, P.M. Variation in the canadian fire weather index thresholds for increasingly larger fires in Portugal. Forests 2019, 10, 838. [CrossRef]

33. Varela, V.; Vlachogiannis, D.; Sfetsos, A.; Politi, N.; Karozis, S. Methodology for the study of near-future changes of fire weather patterns with emphasis on archaeological and protected touristic areas in Greece. Forests 2020, 11, 1168. [CrossRef]

34. Ma, W.; Feng, Z.; Cheng, Z.; Chen, S.; Wang, F. Identifying forest fire driving factors and related impacts in china using random forest algorithm. Forests 2020, 11, 507. [CrossRef]

35. Milanović, S.; Marković, N.; Pamučar, D.; Gigović, L.; Kostić, P.; Milanović, S.D. Forest fire probability mapping in eastern Serbia: Logistic regression versus random forest method. Forests 2020, 12, 5. [CrossRef]

36. Zong, X.; Tian, X.; Yin, Y. Impacts of climate change on wildfires in central asia. Forests 2020, 11, 802. [CrossRef]

37. Nolan, R.H.; Blackman, C.J.; Resco de Dios, V.; Choat, B.; Medlyn, B.E.; Li, X.; Bradstock, R.A.; Boer, M.M. Linking forest flammability and plant vulnerability to drought. Forests 2020, 11, 779. [CrossRef]

38. Balaguer-Romano, R.; Díaz-Sierra, R.; Madrigal, J.; Voltas, J.; Resco de Dios, V. Needle senescence affects fire behavior in aleppo pine (Pinus halepensis Mill.) stands: A simulation study. Forests 2020, 11, 1054. [CrossRef]

39. Luo, K.; Quan, X.; He, B.; Yebra, M. Effects of live fuel moisture content on wildfire occurrence in fire-prone regions over southwest China. Forests 2019, 10, 887. [CrossRef]

40. Della Rocca, G.; Danti, R.; Hernando, C.; Guijarro, M.; Michelozzi, M.; Carrillo, C.; Madrigal, J. Terpenoid accumulation links plant health and flammability in the cypress-bark canker pathosystem. Forests 2020, 11, 651. [CrossRef]

41. Collins, L.; Hunter, A.; McColl-Gausden, S.; Penman, T.D.; Zylstra, P. The effect of antecedent fire severity on reburn severity and fuel structure in a resprouting eucalypt forest in Victoria, Australia. Forests 2021, 12, 450. [CrossRef]

42. Zhang, Y.; Sun, P. Study on the diurnal dynamic changes and prediction models of the moisture contents of two litters. Forests 2020, 11, 95. [CrossRef]

43. Log, T. Modeling drying of degenerated Calluna vulgaris for wildfire and prescribed burning risk assessment. Forests 2020, 11, 759. [CrossRef]

44. Ma, Y.; Tigabu, M.; Guo, X.; Zheng, W.; Guo, L.; Guo, F. Water-soluble inorganic ions in fine particulate emission during forest fires in chinese boreal and subtropical forests: An indoor experiment. Forests 2019, 10, 994. [CrossRef] 